\title{
The Death and Life of Private Landlordism: How Financialized Homeownership Gave Birth to the Buy-To-Let Market
}

\author{
Manuel B. Aalbers, Cody Hochstenbach, Jelke Bosma and Rodrigo \\ Fernandez
}

Paper forthcoming in the journal Housing, Theory and Society

Manuel B. Aalbers, KU Leuven/University of Leuven, Division of Geography \& Tourism, Celestijnenlaan 200E bus 2409, B-3001 Leuven, BELGIUM, manuel.aalbers@,kuleuven.be

Cody Hochstenbach, University of Amsterdam, Department of Geography, Planning and International Development Studies

Jelke R. Bosma, University of Amsterdam, Department of Media Studies

Rodrigo Fernandez, The Centre for Research on Multinational Corporations (SOMO)

\section{Acknowledgements:}

The authors would like to think the reviewers as well as the members of "The Real Estate/Financial Complex" research group for their comments on an earlier draft. Thanks also to Paul de Vries (Kadaster) for kindly sharing the aggregated Land Registry data. This paper is based on a report by the authors (Aalbers et al. 2018) commissioned by the Dutch Socialist Party. Cody Hochstenbach acknowledges the financial support of a VENI grant (VI.Veni.191S.014, "Investing in inequality: how the increase in private housing investors shapes social divides") from NWO, the Dutch Research Council. 


\title{
The Death and Life of Private Landlordism: How Financialized Homeownership Gave Birth to the Buy-To-Let Market
}

\begin{abstract}
The private rental sector (PRS) is making a surprising comeback. A central argument in our paper is that we see the rise of PRS and the associated stagnation of homeownership as springing from the contradictions inherent to financialized homeowner societies. Rather than a feature of either mature or late homeowner societies, contradictions of the promotion of homeownership through the expansion of mortgage markets paved the way for a revival of the PRS. Our case is the Netherlands, but our argument has a wider remit. We sketch the dominant trends in Dutch housing policy and present an overview of the rise of PRS and Buy-To-Let in Dutch cities. We identify how housing policies and realities have driven a shift from a debt-driven to a wealth-driven model of financialization, in which the demand for PRS as an investment class and as a place to live has become central. Ultimately, the revival of private landlordism may amount to property wealth concentration, deepening social divides.
\end{abstract}

\section{Key words:}

Housing; financialization; buy-to-let; real estate investment; private rental sector; Netherlands

\section{Introduction}

The private rental sector (PRS) is making a surprising comeback. After decades of decline, the sector is growing again in many countries, and not so much at the direct expense of social rental sector (SRS) but primarily tied to declining homeownership rates. Whereas Michael Harloe $(1985 ; 1995)$ famously described the PRS as in perpetual decline and the SRS as edging towards residualization, he never wrote the book about the rise of the third major tenure: homeownership. In this paper we will argue that the contradictions of promoting homeownership through the expansion of mortgage markets paved the way for a revival of the PRS. Our case is the Netherlands but our argument is relevant to financialized homeowner societies globally, especially those that, like the Netherlands, developed as a result of socio-political transformations from the 1980s onwards. A central argument in our paper is that we see the growing share of PRS and the associated decline or stagnation of homeownership not necessarily in either mature or late homeowner societies, but primarily as a feature of such financialized homeowner societies. 
In what follows we first present international evidence and theories concerning the rise of PRS in section 2. We show that decades of pro-homeownership policies combined with the gradual but steady erosion of social rent now fuel the revival in private renting. In section 3 we sketch the dominant trends in Dutch housing policy, focusing on all three major tenures as they could be considered communicating vessels. That is, developments in, and policies for specific tenures have implications for other housing tenures. We show that the Dutch national government has made steps to relax regulation and accommodate liberalization on the private-rental market and weakened tenant rights. In so doing, it sets the scene for amplifying social inequalities between the property rich and the property poor. Specifically, financialization allowed one generation to use larger mortgage loans to afford higher house prices, while also benefitting earlier generations of homeowners; but as the limits of financialization come into view, younger generations are unable to acquire larger mortgage loans to make up for the higher house prices. As homeownership is promoted through reducing social rent and expanding credit, house prices are inflated by the increasing stock of mortgage debt, leading to ever-higher price-to-income ratios. This eventually is self-defeating, leading to a surge in PRS and a decline in homeownership rates.

Thus, in section 4 we present an overview of the rise of PRS as a key outcome of promoting financialized, debt-driven homeownership. We distinguish between investments in rental housing by institutional landlords, and those by private individuals. The latter represent a form of private landlordism, which we refer to as Buy-To-Let (BTL). We show that BTL purchases, particularly by individuals with relatively small portfolios, constitute an increasing share of all purchases on the Dutch housing market, and especially so in larger cities and university cities. While smallscale private landlords thus play a central role in the PRS resurgence, institutional investment is also on the rise. Dutch housing policies have increasingly restricted access to social rent to low-income groups, while fuelling house price increases with mortgage debts. As a consequence, a growing number of households fall in-between these two tenures: they have no other option than to resort to private rent. Private investors respond to and accommodate this demand through BTL investments. Mounting concerns exist that particularly BTL investors exacerbate the urban housing crisis: by buying up property, they may drive up house prices and exclude regular house-seekers, i.e. prospective homeowners. Furthermore, the revival of private landlordism may add to social divides (e.g. in terms of wealth accumulation).

In the conclusion we argue that the changing housing policies and realities have fed the demand for PRS as an investment class and as a place to live. We argue these local trends are not part of a 'natural' market process but should be considered the product of both global economic developments and national policies accommodating these changes (cf. Byrne, 2019; Dewilde, 2018). Global developments particularly include the wall of money in search of investments in 
different assets such as real estate (Fernandez and Aalbers, 2016): since the 1980s an increasingly mobile volume of financial capital, in conjunction with a growing global financial infrastructure, operated by an increasingly concentrated financial services industry, has been a driving force in transforming non-financial objects and noncommodified social domains into tradable financial assets. Housing was always an interesting object to feed the assetization hunger of financial markets. Initially, however, it was primarily through mortgage debt and the ability to construct a sizeable and liquid market through securitization that linked high finance with the everyday life of households (Aalbers, 2008). Since the global financial crisis (GFC), monetary conditions pushed investors into riskier and higher yielding assets, which led to an increased appetite for the assetization of real estate itself. Essentially, we identify a shift from a debt-driven to a wealth-driven model of financialization, in which BTL purchases are key. Although there are many peculiarities of the Dutch case, we emphasize the commonalities between financialized homeowner societies and the associated rise of private landlordism springing from the contradictions inherent to such societies. We thus contribute to theories on (post-)homeowner societies and the financialization of housing.

\section{The international rise of private landlordism}

In this section we provide an overview of the international comeback of PRS and discuss the theories mobilized to explain this growth. In doing so, we also explain our position in the debate. In short: we argue that the rise of PRS is the consequence of the contradictions inherent to promoting financialized homeownership. The heuristic of 'financialized homeownership', on the one hand, allows us to analyze the fall and rise of PRS in a relational way, that is, interconnected to both homeownership and SRS. On the other, in opposition to theories that see the rise of PRS as a phenomenon exclusive to 'mature' homeownership societies, we view the investment in PRS as a continuation of the financialization of housing under changing conditions in which homeownership is increasingly out of reach for younger generations while both older generations and institutional investors remain interested in investing in housing and reroute part of their investment stream in PRS.

We can witness the revival of the PRS in countries as diverse as Australia (Hulse and Yates, 2017), Belgium (Verstraete and Moris, 2019), Ireland (Byrne, 2019; Norris and Coates, 2014), New Zealand (Howden-Chapman, 2015), Spain (Byrne, 2019), the UK (Bone, 2014; Kemp, 2015; Ronald and Kadi, 2018) and the US (Schwartz, 2015). Forrest and Hirayama (2015) have argued that the rise is typical of 'mature' homeowner societies, but the Netherlands is not a mature homeowner society. Indeed, the Dutch homeownership rate was as low as $45 \%$ in 1990 , and has in recent years stabilized around 57\% (CBS 2019), despite prior policy ambitions to increase homeownership rates to $65 \%$. If anything, the Netherlands constitutes an 'immature' or 'late' homeowner society. One could argue that the British homeowner 
society - the most studied case of the revival of PRS - is also not that mature and the rise in homeownership rates is a relatively recent phenomenon, with a rapid increase in the 1980s and 1990s, in part as a result of the much-discussed 'Right To Buy' policy (cf. Forrest and Hirayama, 2018). Yet, countries like Australia, Belgium and Spain, which, despite their important differences, could be considered mature homeowner societies, have all seen a rise of PRS as well.

Whatever theory or typology of housing systems one applies, there is a fall in homeownership rates and a rise of PRS across a range of types. We see the shift in both unitary/integrated and dualist rental systems (Kemeny, 1995), across three (Esping-Andersen, 1990) or more welfare regimes (Matznetter and Mundt, 2012), across the four varieties of residential capitalism (Schwartz and Seabrooke, 2009) and in three of the four trajectories of institutional housing structures (Fernandez and Aalbers, 2016). Does this imply that the rise of PRS is omnipresent and we witness a massive convergence of national housing systems? Not exactly. Indeed, in most of these types we can also find countries in which homeownership rates continue to increase and PRS is stable or in decline. In other words: something else is taking place.

The revival of PRS can instead be linked, we argue, to the financialization of housing. Financialization can be defined as "the increasing dominance of financial actors, markets, practices, measurements, and narratives at various scales, resulting in a structural transformation of economies, firms (including financial institutions), states, and households" (Aalbers, 2016: 2). The literature on the financialization of housing has demonstrated how housing is increasingly treated as a financial asset, not only by homeowners but also by financial institutions, investors and private landlords (Fields 2018; Van Loon and Aalbers 2017).

The rise in mortgage debt is particularly striking. It could be argued that the increase in homeownership rates in many countries was enabled by an expansion of mortgage debt in general, and in particular a rise in loan-to-income (LTI) and loan-tovalue (LTV) rates, in combination with medium to long-term low interest rates (Aalbers, 2008). In several countries, such as the UK and the Netherlands, this rise was the result of policy attempts to democratize homeownership access (Elsinga et al., 2016; Saunders 1990) and enabled not only more people to become homeowners but also many households to buy more expensive homes. One important consequence (as well as a way to measure the financialization of housing) is that the rise in mortgage debt outpaced the increase in housing prices, and that both outpaced the rise in income (Fernandez and Aalbers, 2017). This financialization trend is not universal and does not necessarily result in the convergence of housing systems; yet this trend is visible across a wide range of housing systems, not only in Western Europe, North America, and Australia but also in several countries in other (sub-)continents. As this trend is more pronounced in some countries than in others, it may actually result in 
increased divergence between national housing systems (Fernandez and Aalbers, 2016).

We argue that the financialization of housing through mortgage debt is running out of steam and that this is a result of the contradictions of financialized homeownership. Financialization through mortgage debt has reached its limits, triggering the housing finance system to morph into something new. While households were previously the ideal carriers of the practice of financialization, taking on more debt, increasing the circulation of mortgage debt as collateral, the debt-led growth model inflated prices beyond income for too long. As households are increasingly unable to buy at these inflated prices, new carriers of financialization emerged as a substitute.

In his 2008 book on homeowner societies, written before the outbreak of the GFC, Richard Ronald already predicted the 'post-homeownership society', as he noted how it became increasingly difficult, especially for young people, to buy a house, thereby undermining the long-term stability of so-called 'asset-based welfare' (Ronald, 2008). Montgomerie and Büdenbender (2015: 386) have also addressed the contradictions of financialized homeownership, noting fundamental problems in notions of asset-based wealth, which ignore "the temporal and spatial limits of gains from residential housing”. The policy discourses underpinning homeownership are increasingly out of tune with the lived realities of mortgaged homeownership (Fikse and Aalbers, 2020; García-Lamarca and Kaika, 2016; Murphy and Rehm, 2016). Forrest and Hirayama (2015: 239), finally, see the rise of the PRS in mature homeowner societies as "emerging from the 'creative destruction' of postcrisis and post-bubble housing markets". This is concurred by Fields (2018) who sees PRS as a new asset class arising from the ashes of the GFC, built on top of the previous accumulation regime of debt-driven homeownership. Arundel and Doling (2017) cite another contradiction: between growing inequality stemming from the labour market and feeding into the housing market, reducing overall access to homeownership.

The contradictions of financialized homeownership have contributed to the revival of PRS in three interconnected ways that together shape our theoretical framework. First, the debt-driven model of financialized homeownership has allowed a class of homeowners to accumulate substantial stocks of housing wealth. As the gains on capital increasingly outpace those on labour, wealth disparities increase (Piketty 2014). Wealth accumulation, then, becomes more important in class formation and demarcation (Adkins et al. 2019). There are also notable generational dynamics involved, as older generations in particular benefited from relatively easy entry into homeownership and subsequent debt-fuelled price increases (Forrest and Hirayama 2015). These historically specific dynamics have now created a specific generation and class of homeowners able to mobilize their housing wealth to buy more dwellings, thereby forming what could be labeled - albeit with some degree of 
overstatement—a 'generation landlord' (Ronald and Kadi, 2018). Ownership of multiple properties, and the wealth it represents, then becomes even more constitutive of class position (Forrest and Hirayama 2018).

The increase in multiple property ownership among private individuals comes in various guises, including second homes, holiday rentals (Airbnb), speculative empty property, and property to rent out (Kadi et al. 2020). While a small transnational elite exists that buys housing in first and second tier global cities and leisure capitals to safely store their wealth, often leaving those dwellings empty or only living there a few days a year (Fernandez et al., 2016), the vast majority of private landlords are small-scale and invest domestically, typically close to home in local housing markets they are familiar with (Ronald and Kadi, 2018; CBS, 2017). In the UK and Australia, BTL was further promoted, at least for a number of years, through specific BTL mortgages (Kemp 2015). Such mortgages have also been introduced in the Netherlands, though ostensibly remain comparatively small-scale (e.g. NIBC 2018). Favourable tax regimes have further fuelled BTL demand (Pawson and Martin, 2020).

Second, institutional and other professional investors have backed the growth of mortgage markets, especially by buying up large amounts of residential mortgagebacked securities (Aalbers et al., 2011; Gotham, 2009; Wainwright, 2009) and have only become more interested in investments in real estate since the GFC (Van Loon and Aalbers, 2017). Investments in real estate are of course far from new. In times of overaccumulation when other investment opportunities are lacking, excess capital can be channeled into, or switched to, real estate (Harvey, 1982). Real estate then effectively functions as an "overflow tank" for capital to be stored in (Aalbers and Christophers, 2014). What is different from the pre-GFC decades when most investments flowed into owner occupancy, is that private-rental housing has emerged as a more important asset class able to absorb flows of capital (Fields, 2018).

The rise of BTL is also associated with low interest rates, which not only make it cheaper to borrow money but also mean that the rate of return on many other investment classes is considered too low. Furthermore, in the aftermath of the global - or North-Atlantic - financial crisis (GFC), stocks and more complicated financial products were considered less attractive and too risky by small investors (Fernandez and Aalbers, 2016). As mortgage debt is not growing as spectacularly anymore in most of the Global North, and the subzero interest rate environment required higher yielding assets, these investors have ventured out into new markets, including rental markets. The rise of residential Real Estate Investment Trusts (REITs) and other large housing funds is one of the most striking developments in the past decade (Fields, 2018; Waldron, 2018; Wijburg and Aalbers, 2017). Like small investors, institutional investors are also looking for low-risk investments that yield more than, for instance, government bonds. Such investors may invest in new-build PRS, but many private 
equity and hedge funds like Blackstone and Cerberus also buy up large housing portfolios (Aalbers and Holm, 2008; Alexandri and Janoschka, 2018; Fields and Uffer, 2016; Nethercote 2019), which are subsequently transformed into REITs in which institutional investors, like pension funds, are big investors (Wijburg et al., 2018).

Third, demand for renting, particularly in urban locations, has increased. Explanatory factors include the de-standardization of life-course trajectories, where younger adults extend a transitory life phase before settling down. Along with increasing participation in higher education and the ongoing urban concentration of economic activity, this has fuelled demand for rental housing in larger cities (Buzar et al., 2005). Growing numbers of international students and knowledge workers further shape demand for renting (Leyshon and French, 2009; Hochstenbach et al., 2020).

More fundamentally, PRS demand has increased as the result of decreasing access to homeownership among younger adults (Lennartz et al. 2016). For one, in several countries the rules of the mortgage market have become stricter, making it harder to get a mortgage (Forrest and Hirayama 2015). Also, housing is so expensive in many, particularly urban, places that even the very high LTI rates of the pre-GFC years make it difficult to acquire a home (Inchauste et al. 2018). The result is that homeownership markets are increasingly geared towards what Forrest and Hirayama (2015) term "prime households", i.e. households that not only have a high (often dual) income and a secure labour-market position, but who can also bring in equity. Yet, structural labour-market transformations generate a growing precariously employed workforce (Standing, 2011). Wages have not risen and are even lower in some countries for Millennials than they were for the previous generation (Bell and Blanchflower, 2011). Labour-market insecurity and the rise of casual work have also made it harder to qualify for a mortgage or make it too risky to buy a place (Dotti Sani and Acciai, 2018; Nolan et al. 2014). Increased labour precarity thus feeds into housing precarity, amplifying insider-outsider divides across both domains (Arundel and Hochstenbach, 2019). Combine these trends and we see not only an increased supply of rental housing but also an increased demand. On top of this, private landlords now compete with prospective homeowners, resulting in further price increases in those parts of the market that were formerly attainable for starters, thereby exacerbating the housing affordability problem.

\section{Dutch housing tenure policies}

There appears to be a general tendency to regard BTL as the outcome of standalone market forces rather than the specific outcome of national and local housing policies (cf. Hochstenbach and Ronald, 2020; Crook and Kemp, 2019). In this paper we argue that BTL should be considered the outcome of long-term economic and political developments, including broader reforms in both the owner-occupied and rental housing markets. 
For a long time, guaranteeing sufficient affordable housing was seen a central part of the Dutch welfare state (Van der Schaar, 1987). However, the state has redefined its role in recent decades. It did not so much withdraw from the housing market as it has shifted its emphasis completely: homeownership has grown considerably, mortgage interest relief as well as more and larger mortgages have made house prices rise, rental legislation has been relaxed, and housing associationsformerly the champions of the internationally highly acclaimed Dutch SRS - are now embedded in a market context under state supervision rather than part of the long arm of the state (Salet, 1999; Van Gent and Hochstenbach, 2020).

In this section we show that the rise of PRS in general and BTL in particular did not simply come out of the blue. Both long-term policies and recent changes in housing policies play a crucial role. Policy changes regarding the different major tenures-PRS, SRS and owner-occupied homes - do not directly push investment in the housing market, but have shifted the incentives in favour of BTL investment. In other words: we show how the policy changes have first pushed the model of financialized homeownership, but faced with its own contradictions has resulted in an increased demand for PRS as a home and investment. Our intention here is not to provide a full overview of Dutch housing policy changes (see, i.a., Elsinga et al., 2016; Musterd, 2014; Van Gent and Hochstenbach, 2020), but rather to briefly summarize dominant trends.

\section{The end of the mass model of social housing}

Housing policy was a central part of the Dutch welfare state during the twentieth century. Social housing dominated the reconstruction period after the Second World War (Van der Schaar, 1987). Between 1945 and 1985, the share of housing controlled by non-profit housing associations increased from $13 \%$ to almost $40 \%$ (Figure 1). From the end of the 1980s onwards, however, the emphasis shifted to expanding homeownership, at the expense of SRS and especially PRS. The decrease is particularly pronounced in the largest cities that used to be almost exclusively tenants' cities. In 1980, rental housing made up $80 \%$ of the housing stock in the three largest cities, and in Amsterdam even 92\% (Musterd, 2014). Since then, the share of rental housing, in Amsterdam declined to $70 \%$ in 2017, leaving 30\% to owner-occupied housing (CBS, 2019).

In addition, access to the social housing sector has been restricted. In 2011 the Dutch government, under the impetus of a complaint to the European Union by institutional investors active in the PRS, set a maximum pre-tax household income limit of $€ 36,798$ per year $^{1}$ for the SRS. Since then, housing associations have had to lease $90 \%$ of their units to households with an income below this threshold. One consequence is that association tenants increasingly belong to the lowest-income

\footnotetext{
${ }^{1}$ This is the 2018 income limit, subject to annual inflation corrections.
} 
households in the country (SCP, 2017). Social rent thus increasingly functions as a last resort, in line with Harloe's (1995) pessimistic view on the future of the mass social housing model. Those earning slightly above the income limit can hardly get into the SRS anymore, and have to rely on one of the other two major forms of housing tenure (Hochstenbach \& Ronald, 2020). These developments are in line with international policy trends driving SRS residualization, typically characterized by mass sell-offs, overall reductions in SRS size, restricting access to the tenure and marginalizing tenants (e.g. Malpass 2004).

Finally, the (financial) leeway of housing associations has become more limited. This is, at least in part, due to scandals in the SRS - such as the Vestia affair in which a particularly 'entrepreneurial' housing association from the Rotterdam-The Hague metropolitan region lost approximately $€ 2.8$ billion due to betting with derivatives (Aalbers et al., 2017). This put a financial strain on the entire SRS, as other housing associations had to pay for (part of) the losses. The Vestia affair and other high-profile cases of misconduct also meant a severe blow to public and political support for housing associations, ultimately resulting in a stricter state regulation of the sector (Van Gent and Hochstenbach, 2020). Other policy measures such as the Landlord Levy, an additional tax on rent-regulated dwellings introduced as an austerity measure in 2013, have also increased the burden on housing associations. The result is that there is less financial room for manoeuvre, which results in lower rates of new construction and high-level refurbishment. In addition, the additional costs encourage rent increases and home sales, both to owner-occupiers and investors (ibid).

\section{The promotion of financialized homeownership}

The Netherlands is a late homeowner society. The expansion of the owner-occupied sector since the end of the 1980s has been made possible by mortgage interest relief, flexible mortgage lending and increasingly higher LTV and LTI ratios, i.e. through a highly financialized homeownership model (Aalbers, 2008). The mortgage interest relief de facto means that owner-occupied homes are fiscally subsidized, and in theory financially more attainable. Decades of generous mortgage lending and mortgage interest relief have made the Netherlands one of the global champions in mortgage debt. Indeed, Dutch households are among the most indebted worldwide, with a gross-debt-to-income ratio of 199\% in 2018 (down from $232 \%$ in 2010) far surpassing UK and US households (Trading Economics, 2019) and with the highest share of mortgaged homeowners in the EU (EMF, 2018). Whereas consumer credit was 'only' $€ 25$ billion by the end of 2014 , the stock of residential mortgage debt stood at $€ 652$ billion, down from a high of $€ 671$ billion two years previously, but was $€ 664$ billion by the end of 2016 (EMF, 2018). Even though the Netherlands is characterized by particularly high mortgage debt, the expansion of mortgage credit by allowing larger shares of the population to take on larger debts has been central in driving 
homeownership expansion across countries, alongside fiscal and ideological stimulation (Fernandez and Aalbers, 2016; Ronald, 2008). The massive building up of mortgage debt inflated house prices. Rising house prices in turn fuelled the lowering of housing finance standards that enabled a continued growth of the stock of credit, which facilitated a further rise in house prices.

Another contributing factor to the growth of the financialized homeownership model is the increased importance of mortgage securitization. Since the establishment of the market in 1996, securitization has truly taken off in the Netherlands (Aalbers et al., 2011). The outstanding stock of Dutch residential mortgage-backed securities (RMBS) hovers between $€ 190$ billion and $€ 290$ billion between 2010 and 2016, with a downward trend in recent years (EMF, 2018). In other words, roughly one third of outstanding mortgage debt is securitized in the Netherlands. In some years, Dutch securitizations account for approximately $40 \%$ of the Euro market and about one quarter of the overall European RMBS market (AFME, 2018). Given the Netherlands' population of some 17 million people ( $3 \%$ of the EU), it is a huge overrepresentation. At the same time, we witness a rise in select other countries as the European market for RMBS, especially prior to the in other financialized homeownership societies like the UK and Spain (Fernandez and Aalbers, 2016; Wainwright, 2009).

Initially, the governmental promotion of homeownership and the mortgage lenders' policies and practices enabled more households to buy a house (Wind, 2017) and contributed to economic growth. At a time when real wages were hardly keeping up with inflation, it was housing equity that spurred the economy. However, it has also resulted in (urban) house price increases that far outpace the rise in household income. The price-to-income ratio of Dutch houses went up from 56 in 1985, to 109 in 2000 and 114 in 2018, where 100 represents the long-term average (Lennartz et al. 2019; OECD 2019). Homebuyers, however, are increasingly coming up against the limits of affordability after prolonged price increases. Only the historically extremely low interest rates of recent years, and the use of own or family wealth, have been able to maintain a certain level of affordability for some buyers.

Contrary to popular and political discourse that emphasizes how new homeowners have benefitted from the Dutch housing finance system, it is not new homeowners who benefit most, but those who have been homeowners for decades. Financialized homeownership is the most beneficial for those who invested earlier and who were able to invest more (Aalbers, 2008): the "upward pressure on house prices restricts access to homeownership and adds to the wealth of the "insiders" at the expense of the "outsiders"' (Stephens 2007: 218). Whereas many Dutch homeowners were able to build up housing wealth, tenants and prospective buyers were excluded from the greatest household wealth creation in Dutch history. The fault lines between insiders and outsiders follow predictable patterns of class, generation and location (Wind 2017; Arundel 2017). Furthermore, these housing market dynamics are a crucial driver of the in international comparison stark wealth 
inequality in the Netherlands (Van Bavel and Frankema 2017).

The accessibility of the owner-occupied sector was already declining well before the GFC, but has not only become more pronounced but also more politicized since. House prices and sales numbers went into free fall, and in 2014 the share of Dutch homeowners in negative equity peaked at 34\% (CBS 2015) as the combined result of falling prices throughout the country and the surge on interest-only mortgages in the decade preceding the GFC. In response to the financial crisis, mortgage lending criteria have been tightened: LTV and LTI have been cappedalthough with a maximum LTV of $100 \%$ in 2018 it is still the highest in the EU (EMF, 2018) — and stricter conditions have been set.

The playing field on the housing market has changed as a result, strengthening the position of those "prime households" that have a high income, a secure labourmarket position and substantial assets at their disposal. These are typically wealthy homeowners, but also young adults with wealthy parents, and private investors. This has gone at the expense of low and moderate-income households, recent homeowners, those without equity and younger households that are overrepresented among those casually employed or working under precarious labour conditions. Insiders and investors can use their strengths to outbid first-time homebuyers. Since 2013, house prices are on the rise again; in 2017, the average house price in the Netherlands increased by $10 \%$. House price growth in many cities outpaces national-level trends (Hochstenbach and Arundel 2020), e.g. they increased with 38\% in Amsterdam in the 24 months spanning 2016-2017 (NVM, 2019).

\section{Falling between two stools: the rise of the private rental sector}

Recent rental housing policies contribute to a shrinking SRS, which becomes progressively residualized, i.e. the reserve of low-income groups. At the same time, the accessibility of the owner-occupied sector is diminishing. Many households now fall between two stools: they earn too much to qualify for social housing and too little to get a mortgage to buy a home that matches their stage of life and household. As social housing is allocated through regional waiting lists and distribution systems, newcomers from other parts of the country or abroad are not able to directly enter the SRS at all. As a result, they are dependent on the PRS. The increased demand for PRS makes investment in the sector more attractive. But in order to explain the surge in PRS, and in particular BTL investment, we also need to understand the recent policy shift in favour of deregulated — or more accurate: liberalized — rents.

In recent years the Dutch national government has become proactive in directly encouraging PRS growth. Expansion of the liberalized rental market - and in particular the so-called "middle segment" with monthly rents between roughly $€ 720$ 
and $€ 1000^{2}$ - is now being presented as the solution for accommodating households that fall between two stools (Hochstenbach and Ronald 2020). The Coalition Agreement of the Rutte III Cabinet, for example, prioritizes growth of the liberalized PRS. The National Housing Agenda, presented in May 2018, further emphasizes the expansion of the middle segment, including through the sale of units by housing associations to investors. Furthermore, until early 2020 the Dutch Ministry of the Interior hosts a dedicated website (www.investingindutchhousing.nl) where the Dutch SRS was promoted as an appealing investment object for foreign investors, offering the prospect of future rent increases. The overarching idea is that all efforts that increase the supply of liberalized private-rental units are direly needed — whether this is through BTL, portfolio buy-ups or new construction.

More generally speaking, decades of pro-homeownership policies have contributed to substantial increases in house prices. There is strong political, electoral and societal support for high and increasing house prices. Incumbent owner-occupiers —in many countries a majority population - typically support high(er) house prices, as these are associated with wealth accumulation, feelings of financial security and increased consumption potential (Ansell, 2014; Campbell and Cocco, 2007). Conversely, decreasing prices may lead to indebtedness, exposure to risk and an inability to move. The broad support base for high house prices enhances housing's reputation as a safe investment.

National government typically responds to price drops with corrective measures aimed to prop up prices. For instance, during the GFC the Dutch national government lowered stamp duties (from $6 \%$ to $2 \%$ ) and allowed for tax-free intergenerational transfers of up to $€ 100,000$ to support with house purchases. These measures were temporary responses to the crisis with the aim of increasing transaction numbers and prices again, but have since become accepted as permanent. The insurance that governments will go to great lengths to accommodate house-price increases, enhances investors' appetite for real estate (Crouch, 2009; Watson, 2010).

In addition, some specific measures have been taken to make investing in rental properties more attractive. For example, since October 2015, the taxable value of a home has been included in the home valuation system determining rent levels. The result is that in places with high real estate values - in practice first and foremost select cities and urban regions - a rental home can easily be transferred from the regulated segment to the liberalized sector when new tenants move in. This allows landlords to charge higher rents and makes BTL more attractive. Since October 2016, the valuation system was further relaxed by allowing the construction of small but rent-liberalized housing units in Amsterdam and Utrecht, the two most expensive cities. As of July 1, 2016, private landlords also can offer temporary leases of a

${ }^{2}$ All rents above $€ 720$ are liberalized, while those lower than that are regulated. The $€ 1000$ rent is considered the maximum reasonably affordable for middle-income groups. 
maximum of two years, where contracts of indefinite duration were previously standard. This means a weakening of rent protection in favour of landlords.

In sum, after decades of promoting first SRS housing and then, financialized homeownership, the SRS is slowly but progressively shrinking while homeownership growth has stalled as the tenure is increasingly unattainable for many households. On the one hand, this has left a growing group of households with only one option: seeking shelter in the PRS. On the other hand, housing policy has made investing in the PRS more attractive. Finally, macroeconomic developments and monetary policies, typically located at the European or global level, have also pushed investment in real estate (Fernandez and Aalbers, 2016; Fields, 2018; Van Loon and Aalbers, 2017).

Interestingly, throughout 2020 a countermovement in policy has become increasingly discernable. While national policy continues to promote overall PRS growth, some measures have been implemented to curb BTL purchases. In September 2020, national government increased stamp duties for BTL investors from $2 \%$ to $8 \%$, while exempting first-time buyers under the age of 35. In May 2020, it already announced to cap maximum rent increases for incumbent tenants in the rentliberalized sector (though the proposed maximum of inflation plus $2.5 \%$ is unlikely to have a notable impact, as it is well above average annual increases). Furthermore, several municipalities have implemented measures to limit or forbid BTL purchases in specific parts of the housing stock (e.g. new constructions) or in specific neighbourhoods. These measures follow increasing concerns about potentially deleterious effects of BTL investors on the housing market such as the crowding out of young starter households. At the same time, Covid-19 has threatened job security, especially for younger households, further frustrating access to mortgage loans, but has also increased the appetite of cash-rich investors, both older generations of homeowners and institutional investors. As our data only cover the period up until 2017, we cannot yet gauge the impacts of either this policy shift or of Covid-19.

\section{The rise of Buy-To-Let in the Netherlands}

In the previous section we have discussed how the contradictions of financialized homeownership and the squeeze of the SRS have made the PRS an attractive alternative for both households and investors. In this section, we show to what extent and where we see the materialization of the rise of PRS in the Netherlands.

Between 2012 and 2017, the Dutch PRS grew in almost all regions of the Netherlands, adding a total of some 160,000 homes to the sector, a $19 \%$ increase (CBS, 2019). As a result, the share of PRS increased from $11.7 \%$ to $13.3 \%$ of the total housing stock. The increase was particularly strong in the four largest municipalities -Amsterdam, Rotterdam, The Hague and Utrecht, with a combined population of 
2.35 million, or $14 \%$ of the Dutch population - where almost 42,000 PRS dwellings were added. To illustrate: the total housing stock in these four cities increased by 45,000 dwellings during this period, revealing the central role of the PRS in urban growth. The quick rise in PRS represents a major trend reversal: until the outbreak of the GFC, the PRS experienced decades of continuing contraction. Furthermore, the revival of the PRS is related to an internal restructuring of the PRS: where most private rental homes were previously offered at low rents (Aalbers, 1999; Priemus, 1998), growth is currently concentrated in the more expensive liberalized part of the sector (Hochstenbach and Ronald, 2020).

The growth of the PRS can be achieved in various ways: through BTL purchases, through new construction, and through the acquisition of housing portfolios from housing associations. It is important to make a clear distinction between the different types of investors, with different interests and strategies, choosing different ways to expand their PRS portfolio. The final consequences for the housing market may also differ. Not all investments in rental properties can therefore be classified as BTL. In this section we first look at institutional investors before discussing the rise of BTL. Whereas the increased attraction of private rental housing for small, BTL landlords relates to the first set of theories discussed in section 2 (wealth accumulation, which is increasingly housing-led, not only feeds inequality but also the development of "generation landlord"), the parallel participation of institutional investors in the PRS relates to the second set of theories (in the post-GFC environment of low interest rates and limited alternative low-risk investment classes, residential real estate becomes an even more attractive sector to switch capital to). This should then be related to the previous section and the third set of theories in section 2 which suggest that demand for PRS as place to live has increased due to the combined effects of labour market insecurity and the shaping of insider/outsider dynamics in the housing markets.

\section{Institutional investors}

Institutional investors, primarily pension funds, manage large sums of capital, which make them potentially important players in the housing market. From 2014 onwards there has been a substantial increase in investments in both existing rental properties and new-build rentals by institutional investors (CBS, 2018). Already a few years earlier, since 2010, we see a rise in the number of housing units that institutional investors buy from housing associations (Figure 2). The before-mentioned derivatives scandal at housing association Vestia plays an important part here. As a result of this affair, Vestia had to sell thousands of its 90,000 units, but as other associations also had to contribute financially to a solidarity levy, some of them may also have increased their sales (Aalbers et al., 2017). Interestingly, while housing associations structurally sell more units to private households than to institutional investors, we can see a sharp decrease in such sales since 2014 (Figure 2). This timing is no 
coincidence: it is around this time that entry into homeownership becomes more difficult to younger and lower-income households, as described in the previous section. Housing associations, who see themselves forced to keep sales up, thereby shift sales to a more abled buyer: institutional investors.

Private investors have also become much more active in new construction (Figure 3). Throughout the 2008-2013 crisis years, (mostly domestic) private investors were involved in 1,000 to 2,000 new constructions annually. Since then, their activities have boomed. In 2018, Dutch investors invested in over 9,000 newbuild dwellings, and foreign investors in over 8,000 dwellings. Such new constructions help to alleviate some housing-market pressures, though predominantly in higher-end segments. Although no information is available on rent levels, the vast majority of these new rental dwellings are offered in the rent-liberalized sector, with monthly rents starting from $€ 720$.

\section{Small and medium-sized private landlords}

Recent discussions in Dutch media and public debate on the nature of the emerging housing affordability crisis often focus on BTL purchases. This form of landlordism indeed plays a central role in current wealth-driven housing dynamics, with private individuals channelling their wealth into the housing market. The group of BTL investors consists of both small, private investors and professional landlords. Private investors include, for example, investors who buy a property as an old-age provision, who buy property rent to children or friends, who have inherited a property or who rent out a property pending sale. Profit motives are not always decisive. For professional investors often with larger real estate portfolios who purchase and lease properties on a commercial basis (and sometimes resell them again), a profit motive plays a more prominent role.

Figure 4 shows the development of purchases by private individuals (rather than commercial landlords) for lease as a share of the total number of transactions in the period 2006 up to and including the third quarter of 2016. The data presented here include the purchases of third up to fiftieth dwellings owned by private individuals. In the case of second home purchases, it is difficult to ascertain these are BTL transactions for various reasons. Most importantly, regular owner-occupiers may have bought a new house prior to selling their old one. In subsequent analyses we therefore primarily focus on the purchase of third to fiftieth dwellings. By excluding the purchase of secondary property, we somewhat underestimate BTL shares. Trends over time are highly similar when including second properties though. The data also include transactions between landlords, implying that these figures cannot be used as direct evidence of owner-occupied homes being converted into rental properties. They do, however, provide a clear indication of the share of BTL purchases, per city. 
In the Netherlands as a whole, the share of BTL among all transactions by private individuals increased by $79 \%$ between 2006 and 2016, from 3.3\% to 5.8\%. In Amsterdam, Rotterdam and The Hague relatively more homes are purchased by small investors. In 2010, they accounted for nearly $7 \%$ of all home purchases in Amsterdam; in 2016 for nearly 13\%. The Hague and Rotterdam also saw a doubling in BTL sales, up to, respectively, $11 \%$ and $10 \%$ in 2016 . The figures for Utrecht, the fourth largest city of the country, are much lower and fluctuate around the national average. In all cases, the BTL shares started to increase from 2010-2012 onwards. If we would also include the purchase of second properties, the 2016 shares are substantially higher: $11 \%$ in the Netherlands, $22 \%$ in Amsterdam, 16\% in Rotterdam, $18 \%$ in The Hague and $11 \%$ in Utrecht (see Figure 5).

More strikingly, we do not find the highest BTL shares in the largest cities, but in a few medium-sized cities (Figure 5). Leader of the pack is Maastricht, where $20 \%$ of all house purchases in 2016 can be earmarked as BTL (or 27\% when including second properties). Groningen and Amstelveen are also in the top three. Maastricht and Groningen are both student cities with a large student population from abroad, generating demand for private rental housing. In comparison to many other student cities, these two cities also have a relatively small formal student-housing sector, thereby increasing dependency on PRS. Amstelveen is a suburb that borders Amsterdam to the south, tucked between the new 'Zuidas' CBD and the airport, and is particularly popular among high-earning knowledge workers - also a group that the more expensive PRS caters to. In addition, the second largest university of Amsterdam is right across the Amstelveen-Amsterdam municipal border. These interurban disparities highlight that the demand for PRS housing from specific population groups is important in fuelling BTL investments.

Further analyses reveal that particularly units smaller than fifty square meters are overrepresented among BTL purchases. Nationally, $28 \%$ of home sales in this category are BTL (38\% when including second dwellings). BTL is also overrepresented in the purchase of dwellings up to 75 square meters. These figures suggest that especially households looking for small homes, such as first-time buyers, single people and seniors, may face competition from landlords in the owner-occupied market. Relatedly, BTL investments concentrate in the cheaper segments of the housing market when looking at total purchase prices.

\section{Conclusion}

This paper has unravelled the recent revival of private landlordism in the Netherlands. First, we have explained that the recent revival of PRS does not emerge out of thin air, but is the outcome of decades of promoting homeownership in a financialized homeowner society. Second, national housing policy and global economic and monetary developments have further enhanced real estate's appeal as an asset class. 
Third, we have empirically shown the multiple paths through which current PRS growth is achieved. That is, the increase in BTL purchases does not stand alone, but is embedded within a broader revival of private renting. Fourth, we have analysed the geography of the rise of PRS and BTL, pointing to the local effects in specific cities. Below, we highlight the various ways in which our findings contribute to the broader literature.

In section 2 we have discussed three sets of literatures that help us to explain the rise of PRS in the Netherlands and elsewhere. The first set argues that wealth accumulation, which is increasingly housing-led, not only feeds inequality but also the development of a "generation landlord". In the Netherlands, as in other financialized homeowner societies, we see how the promotion of homeownership through mortgage markets benefitted a class and generation of households, who saw their housing wealth increase. Particularly striking is how BTL transactions have almost doubled in just six years and now make up a large share of the housing sales in the three largest cities and particularly in medium-sized student cities.

The second set of theories suggests that in the post-GFC environment of low interest rates and limited alternative low-risk investment classes, residential real estate becomes an even more attractive sector to switch capital to. This is something that is becoming visible in the Netherlands as well. Relevant to both sets of explanations, macro-economic developments and monetary policies have made PRS an attractive investment class for both institutional and small investors, not just in the Netherlands but throughout much of the developed world. In addition, Dutch housing policies, as in several other countries, have shifted the balance of power between tenants and landlords in favour of the latter. It is now easier to deregulate or liberalize rents since short-term rental contracts have been introduced, granting greater freedom and potentially higher rents to landlords.

But not only the demand for PRS as an investment but also as a home increases, something the third set of theories-looking at the interaction of labour market insecurity and the shaping of insiders/outsider dynamics in the housing markets - reflects on. As financialization implied that housing prices increased faster than incomes, housing became increasingly unaffordable to large parts of the population, in particular younger households and others who did not have the opportunity to build up any housing wealth yet. Low interest rates and a further expansion of mortgage lending were lessening the effects of rising house prices for some years, but the combination of the GFC, negative equity, less lenient mortgage provision and a more flexible labour market implied that mortgage loans became harder to get by. More specifically for the Netherlands, we also see a slow but progressive residualization of the - formerly mass - SRS. An increasing number of households falls between two stools: too poor or too casually employed to get a mortgage loan and too rich or moved too recently to get into social housing. 
One of the critical elements of the increase in BTL demand and PRS investment is the extension of the price range of the housing stock. Previously, levels of mortgage debt and prices moved in tandem, as the latter were ultimately limited by debt-to-income levels. Now, these two have been decoupled as prices can continue to grow on the back of BTL demand, representing a wealth-driven dynamic on top of previous debt-driven price inflation. This signals a fundamental shift in the life cycle of housing financialization in the Netherlands as well as in other countries that have witnessed parallel trends. The decoupling between the rise of house prices and mortgage debt is a fundamental shift that represents an important modification to the financialization of housing literature.

The decoupling between mortgage debt and price levels can continue as long as increasing house prices do not substantially hurt investor yields. In a low interest rate situation, rates of return on other low-risk asset classes such as bonds often remain lower. Indeed, the housing financialization literature has pointed at the increased demand for housing as an investment because it is still considered a relatively low-risk compared to, for instance, stocks, while allowing for higher yields than government bonds or savings accounts (Fernandez and Aalbers, 2016).

Furthermore, as housing supply is not keeping up with demand and prices continue to increase, investors may be able to do the same with rents, augmenting income. A recent Dutch study showed BTL investments remain lucrative despite notable increases in purchase prices (Conijn et al., 2019). Investors may furthermore factor house price increases into housing-wealth accumulation prospects.

As in other countries, the shifting balance between the three major tenures implies deeper inequalities along lines of class, generation and location (Arundel, 2017; Hulse et al., 2019; Ronald and Kadi, 2018; Stephens, 2007). Wealth increasingly concentrates among long-term homeowners, typically middle- and higher income households (Wind, 2017). The latter see the housing market as an attractive place to store their assets. The purchase of an additional home can serve as retirement provision, insurance against setbacks or future pocket money for the children (Doling and Ronald, 2010). Such investment strategies can be seen as emblematic of "the return of the rentier" who primarily extracts rather than creates value and increasingly does so through debt-based speculation (Hudson 2012). Younger generations, as a consequence, are confronted with a much less accessible and affordable housing market, certainly if they cannot count on parental support (McKee, 2012; Lennartz et al., 2016; Hochstenbach 2018). On the basis of our findings, we suggest a tripartite development in economic prospects. On the top there are multiple property owners who can mobilize their real estate to achieve further wealth accumulation; in the middle other owner-occupiers, many of whom benefit from house-price appreciation but also including many homeowners with high LTI and LTV ratios who are at risk of loosing out when house prices decline, relationships break up or unemployment hits; and at the bottom, tenants, many of whom are confronted with increasing rent burdens 
(cf. Forrest and Hirayama, 2018; Kadi et al., 2020). Such a development would have important implications for economic, social and political disparities and warrants further research. The focus on not only those excluded from homeownership but also on rentiers is a key contribution to the literature on (post-)homeowner societies.

Finally, we contribute to the literatures on housing financialization and the rise or PRS, by explaining why we see the rise of PRS and the associated decline or stagnation of homeownership not necessarily in either mature or late homeowner societies, but primarily as a feature of financialized homeowner societies. The financialized homeownership society is embedded in a broader political economy characterized by a "finance-dominated accumulation regime" (Boyer, 2000;

Stockhammer, 2004). Within this regime, we see a distinctive line of government policy that Crouch (2009) and Watson (2010), respectively, have dubbed "privatized Keynesianism" and "house price Keynesianism", i.e., both a way to fuel the economy by propping up consumption and to "compensate" labour for decades of negligible or even negative real income growth. Along similar lines, Schwartz (2012) points to the central role of housing wealth-based consumption in the transformation of the political economy. Privatized Keynesianism and financialized homeownership were first presented as a solution to overcome earlier contradictions, but the regime has ran into its limits and private landlordism — partly 'rebranded' as corporate landlordism and buy-to-let - come to the fore as the next 'solutions'. Although the rise of PRS is a pragmatic response for households who fall between two stools, it comes with its own set of contradictions, which—no doubt—will result in another regime shift in the future. This will not only result in a further restructuring of the different housing tenures but also in a new set of socio-economic consequences. 


\section{References}

Aalbers, M. (1999). Particuliere verhuur en de onderkant van de markt. Rooilijn 32(2): 81-86.

Aalbers, M.B. (2008). The financialization of home and the mortgage market crisis. Competition \& Change, 12(2): 148-166.

Aalbers, M.B. (2016). The Financialization of Housing: A Political Economy Approach. London: Routledge.

Aalbers, M.B. (2017a). The variegated financialization of housing. International Journal of Urban and Regional Research 41(4): 542-554.

Aalbers, M.B., \& Christophers, B. (2014). Centring housing in political economy. Housing, Theory and Society, 31(4), 373-394.

Aalbers, M.B. and Holm, A. (2008). Privatising social housing in Europe: The cases of Amsterdam and Berlin. In: Adelhof K, Glock B, Lossau J, et al. (eds) Urban Trends in Berlin and Amsterdam. Berlin: Berliner Geographische Arbeiten, Humboldt Universität zu Berlin, pp.12-23.

Aalbers, M.B., Engelen, E. and Glasmacher, A. (2011). 'Cognitive closure' in the Netherlands: Mortgage securitization in a hybrid European political economy. Environment and Planning A 43(8): 1779-1795.

Aalbers, M.B., Loon, J. van, \& Fernandez, R. (2017). The financialization of a social housing provider. International Journal of Urban and Regional Research, 41(4), 572-587.

Aalbers, M.B., Bosma, J.R., Fernandez, R. \& Hochstenbach, C. (2018). Buy-to-let gewikt en gewogen. Leuven/Amsterdam: KU Leuven \& Universiteit van Amsterdam.

Adkins, L., Cooper, M., \& Konings, M. (2019). Class in the 21st century: Asset inflation and the new logic of inequality. Environment and Planning A: Society and Space. Online First.

Aedes.nl. Ontwikkeling woningvoorraad corporaties 2007-2016. https://www.aedes.n1/feitenen-cijfers/woning/hoe-ontwikkelt-het-bezit-van-corporaties-zich/expert-hoeontwikkelt-het-bezit-van-corporaties-zich.html, geraadpleegd 20-5-2018.

AFME (2018) Securitisation Data Report: European Structured Finance Q2. London/ Brussels/Frankfurt: Association for Financial Markets in Europe.

Alexandri, G., \& Janoschka, M. (2018). Who loses and who wins in a housing crisis? Lessons from Spain and Greece for a nuanced understanding of dispossession. Housing Policy Debate, 28(1): 117-134.

Ansell, B. (2014). The political economy of ownership: Housing markets and the welfare state. American Political Science Review, 108(2), 383-402.

Arundel, R. (2017). The end of mass homeownership? Housing career diversification and inequality in Europe. PhD Dissertation. Amsterdam: Universiteit van Amsterdam.

Arundel, R., \& Doling, J. (2017). The end of mass homeownership? Changes in labour markets and housing tenure opportunities across Europe. Journal of Housing and the Built Environment, 32(4), 649-672.

Arundel, R., \& Hochstenbach, C. (2019). Divided access and the spatial polarization of housing wealth. Urban Geography, Online First. DOI: $10.1080 / 02723638.2019 .1681722$.

Bell, D.N., \& Blanchflower, D.G. (2011). Young people and the Great Recession. Oxford Review of Economic Policy, 27(2), 241-267.

Bone, J. (2014). Neoliberal Nomads: Housing Insecurity and the Revival of Private Renting in the UK. Sociological Research Online 19(4): doi:10.5153/sro.3491.

Boyer, R. (2000) Is a finance-led growth regime a viable alternative to Fordism? A preliminary analysis. Economy and Society 29(1): 111-45.

Buzar, S., Ogden, P. E., \& Hall, R. (2005). Households matter: the quiet demography of urban 
transformation. Progress in Human Geography, 29(4), 413-436.

Byrne, M. (2019): Generation rent and the financialization of housing: a comparative exploration of the growth of the private rental sector in Ireland, the UK and Spain, Housing Studies, DOI: 10.1080/02673037.2019.1632813.

Campbell, J.Y., \& Cocco, J.F. (2007). How do house prices affect consumption? Evidence from micro data. Journal of Monetary Economics, 54(3), 591-621.

CBS (2015). Minder huizen onder water. The Hague: Centraal Bureau voor de Statistiek. Accessed online: https://www.cbs.nl/nl-nl/nieuws/2015/44/minder-huizen-onderwater

CBS (2017). Haalbaarheidsstudie onderscheid particuliere verhuurders van woningen. The Hague: Centraal Bureau voor de Statistiek.

CBS (2018). Beleggingen in miljarden Euros in woningen in Nederland door institutionele beleggers. The Hague: Centraal Bureau voor de Statistiek.

CBS (2019). Eigendom woningvoorraad. The Hague: Centraal Bureau voor de Statistiek.

Conijn, J., Meertens, V., \& Schilder, F. (2019) Buy-to-let verdringt starter van de koopwoningmarkt. Amsterdam: Amsterdam School of Real Estate.

Crook, T., \& Kemp, P.A. (2019) In search of profit: Housing association investment in private rental housing. Housing Studies, 34(4), 666-687.

Crouch, C. (2009). "Privatised Keynesianism: An Unacknowledged Policy Regime.” The British Journal of Politics and International Relations 11: 382-399.

Dewilde, C. (2018). Explaining the declined affordability of housing for low-income private renters across Western Europe. Urban Studies, 55(12), 2618-2639.

DNB (2019). Statistisch Nieuwsbericht: Hypotheekverstrekking door banken loopt terug. Accessed online: https://www.dnb.nl/nieuws/nieuwsoverzicht-en-archief/statistischnieuws-2019/dnb383813.jsp

Doling, J., \& Ronald, R. (2010). Home ownership and asset-based welfare. Journal of Housing and the Built Environment, 25(2), 165-173.

Dotti Sani, G. \& Acciai, C. (2018). Two hearts and a loan? Mortgages, employment insecurity and earnings among young couples in six European countries. Urban Studies, 55(11), 2451-2469.

Elsinga, M., Priemus, H. \& Boelhouwer, P. (2016). Milestones in housing finance in the Netherlands, 1988-2013. In: J. Lunde and C. Whitehead (eds) Milestones in European Housing Finance, 255-272. Oxford: Wiley.

EMF (2018) Hypostat 2017. Brussels: European Mortgage Federation.

Esping-Andersen, G. (1990). The Three Worlds of Welfare Capitalism. John Wiley \& Sons.

Eurostat (2016) Income and Living Conditions. Brussels: Eurostat.

Fernandez, R., \& Aalbers, M.B. (2016). Financialization and housing: Between globalization and Varieties of Capitalism. Competition \& Change, 20(2), 71-88.

Fernandez, R. \& Aalbers, M.B. (2017) Housing and capital in the 21st century: realigning housing studies and political economy. Housing, Theory and Society 34(2): 151-158.

Fernandez, R., Hofman, A., \& Aalbers, M.B. (2016). London and New York as a safe deposit box for the transnational wealth elite. Environment and Planning A, 48(12), 2443-2461.

Fields, D. (2018) Constructing a new asset class: Property-led financial accumulation after the crisis. Economic Geography 94(2): 118-140.

Fields, D. and Uffer, S. (2016) The financialisation of rental housing: A comparative analysis of New York City and Berlin. Urban Studies 53(7): 1486-1502.

Fikse, E. and Aalbers, M.B. (2020) The really big contradiction: homeownership discourses in times of financialization. Housing Studies, DOI: 10.1080/02673037.2020.1784395. 
Forrest, R., \& Hirayama, Y. (2015). The financialisation of the social project: Embedded liberalism, neoliberalism and home ownership. Urban Studies, 52(2), 233-244.

Forrest, R. and Hirayama, Y. (2018). Late homeownership and social re-stratification. Economy and Society 47(2): 257-279.

García-Lamarca, M. and Kaika, M. (2016). 'Mortgaged lives': the biopolitics of debt and housing financialisation. Transactions of the Institute of British Geographers 41(3): 313-327.

Gotham, K.F. (2009) Creating liquidity out of spatial fixity: The secondary circuit of capital and the subprime mortgage crisis. International Journal of Urban and Regional Research 33(2): 355-71.

Harloe, M. (1985) Private Rented Housing in the United States and Europe. New York: St. Martin's.

Harloe, M. (1995) The People's Home: Social Rented Housing in Europe \& America. Cambridge: Blackwell.

Harvey, D. (1982). The Limits to Capital. Oxford: Blackwell.

Hochstenbach, C. (2018). Spatializing the intergenerational transmission of inequalities: Parental wealth, residential segregation, and urban inequality. Environment and Planning A: Economy and Space, 50(3), 689-708.

Hochstenbach, C. and Arundel, R. (2020) Spatial housing market polarisation: national and urban dynamics of diverging house values. Transactions of the Institute of British Geographers, 45(2), 464-482.

Hochstenbach, C. and Ronald, R. (2020) The unlikely revival of private renting in Amsterdam: Re-regulating a regulated housing market. Environment and Planning A: Economy and Space. Online First, DOI: 0308518X20913015.

Hochstenbach, C., Wind, B., \& Arundel, R. (2020). Resurgent landlordism in a student city: urban dynamics of private rental growth. Urban Geography. Online First, DOI: $10.1080 / 02723638.2020 .1741974$.

Howden-Chapman, P. (2015). Home Truths: Confronting New Zealand's Housing Crisis. Wellington: Bridget Williams Books.

Hudson, M. (2012). The Bubble and Beyond: fictitious capital, debt deflation and the global crisis. Dresden: ISLET.

Hulse, K., and J. Yates. (2017). "A Private Rental Sector Paradox: Unpacking the Effects of Urban Restructuring on Housing Market Dynamics.” Housing Studies 32 (3): 253270.

Hulse, K., A. Morris and H. Pawson (2019) Private Renting in a Homeowning Society: Disaster, Diversity or Deviance? Housing, Theory and Society, 36:2, 167-188.

Inchauste, G., Karver, J., Kim, Y.S., Jedil, M.A. (2018). Living and Leaving. Housing, Mobility and Welfare in the European Union. Washington DC: World Bank.

Kadi, J., Hochstenbach, C. \& Lennartz, C. (2020). Multiple property ownership in times of late homeownership: a new conceptual vocabulary. International Journal of Housing Policy, 20(1), 6-24.

Kemeny, J. (1995). Theories of power in the three worlds of welfare capitalism. Journal of European Social Policy, 5(2), 87-96.

Kemp, P.A. (2015). Private Renting after the Global Financial Crisis. Housing Studies 30 (4): 601-620.

Lennartz, C., Arundel, R., \& Ronald, R. (2016). Younger adults and homeownership in Europe through the global financial crisis. Population, Space and Place, 22(8), 823-835. 
Lennartz, C., Baarsma, B., \& Vrieselaar, N. (2019). Exploding House Prices in Urban Housing Markets: Explanations and Policy Solutions for the Netherlands. In: Nijskens, R., Lohuis, M., Hilbers, P. \& Heeringa, W. (Eds) Hot Property (pp. 207-221). Dordrecht: Springer.

Leyshon, A., \& French, S. (2009). 'We all live in a Robbie Fowler house': The geographies of the buy to let market in the UK. The British Journal of Politics and International Relations, 11(3), 438-460.

McKee, K. (2012). Young people, homeownership and future welfare. Housing Studies, 27(6), 853-862.

Malpass, P. (2004). Fifty years of British housing policy: Leaving or leading the welfare state?. European Journal of Housing Policy, 4(2), 209-227.

Matznetter, W. \& Mundt, A. (2012) Housing and welfare regimes, in: D.F. Clapham, W. Clark \& K. Gibb (Eds) The SAGE Handbook of Housing Studies, pp. 274-294 (London: Sage).

Ministry of the Interior (2019) Staat van de Volkshuisvesting 2019. The Hague: Ministry of the Interior.

Montgomerie, J. and Büdenbender, M. (2014) Round the Houses: homeownership and failures of asset-based welfare in the United Kingdom. New Political Economy 20(3): 386-405.

Murphy, N.Z.L., \& Rehm, M. (2016). Homeownership, asset-based welfare and the actuarial subject: Exploring the dynamics of ageing and homeownership in New Zealand. In: Cooke, N., Davison, A. \& Crabtree, L. (Eds) Housing and Home Unbound (pp. 53-69). New York/London: Routledge.

Musterd, S. (2014). Public housing for whom? Experiences in an era of mature neoliberalism: The Netherlands and Amsterdam. Housing Studies, 29(4), 467-484.

Nethercote, M. (2019). Build-to-Rent and the financialization of rental housing: future research directions. Housing Studies, Online first, DOI: 10.1080/02673037.2019.1636938.

NIBC (2018). Annual report 2018. The Hague: NIBC Bank N.V.

Nolan, B., Salverda, W., Checchi, D., Marx, I., McKnight, A., Tóth, I.G., \& van de Werfhorst, H.G. (Eds.). (2014). Changing inequalities and societal impacts in rich countries: thirty countries' experiences. OUP Oxford.

Norris, M., and Coates, D. (2014). How Housing Killed the Celtic Tiger: Anatomy and Consequences of Ireland's Housing Boom and Bust. Journal of Housing and the Built Environment 29 (2): 299-315.

NVM (2019). Overzicht transactieprijzen woningen bestaande bouw in duizenden euro's Nieuwegein: Nederlandse Vereniging van Makelaars en Taxateurs.

OECD (2019). Analytical house price indicators. Accessed online: https://stats.oecd.org/ Index.aspx?DataSetCode=HOUSE PRICES.

Pawson, H., \& Martin, C. (2020). Rental property investment in disadvantaged areas: the means and motivations of Western Sydney's new landlords. Housing Studies, Online First, DOI: 10.1080/02673037.2019.1709806.

Priemus, H. (1998). Commercial rented housing: two sectors in the Netherlands. Netherlands journal of housing and the built environment, 13(3), 255-277.

Ronald, R. (2008) The Ideology of Home Ownership: Homeowner Societies and the Role of Housing. Basingstoke: Palgrave Macmillan.

Ronald, R. and Kadi, J. (2018) The revival of private landlords in Britain's posthomeownership society. New Political Economy, 23(6), pp. 786-803.

Salet, W.G.M. (1999). Regime shifts in Dutch housing policy. Housing Studies, 14(4), 54757. 
Saunders, P. (1990). A Nation of Home Owners. London: Unwin Hyman.

Schwartz, A. (2015). Housing Policy in the United States. 3rd ed. New York: Routledge.

Schwartz, H.M. (2012) Housing, the welfare state, and the global financial crisis: What is the connection? Politics and Society, 40(1): 35-58.

Schwartz, H.M., \& Seabrooke, L., eds (2009). The Politics of Housing Booms and Busts. Basingstoke: Palgrave Macmillan.

SCP (2017). De sociale staat van Nederland. Den Haag: Sociaal en Cultureel Planbureau.

Stephens, M. (2007) Mortgage market deregulation and its consequences, Housing Studies 22(2): 201-220.

Stockhammer, E. (2004) Financialisation and the slowdown of accumulation. Cambridge Journal of Economics, 28(5): 719-41.

Standing, G. (2011). The Precariat: The New Dangerous Class. London: Bloomsbury.

Trading Economics (2019). Netherlands Households Debt To Income. Accessed online: https://tradingeconomics.com/netherlands/households-debt-to-income

Van der Schaar, J. (1987). Groei en bloei van het Nederlandse volkshuisvestingsbeleid: Volkshuisvesting in theorie en praktijk. Delft: Delft University Press.

Van Bavel, B.J.P., \& Frankema, E.H.P. (2017). Wealth inequality in the Netherlands, c. 1950 2015: The paradox of a northern European welfare state. Tijdschrift voor Sociale en Economische Geschiedenis, 14(2), 29-62.

Van Gent, W., \& Hochstenbach, C. (2020). The neo-liberal politics and socio-spatial implications of Dutch post-crisis housing policies. Submitted paper International Journal of Housing Policy, 20(1), 156-172.

Van Loon, J. and M.B. Aalbers (2017) How real estate became 'just another asset class': the financialization of the investment strategies of Dutch institutional investors. European Planning Studies 25(2), 221-240.

Verstraete, J., and M. Moris. 2019. "Action-reaction. Survival strategies of tenants and landlords in the private rental sector in Belgium. Housing Studies 34(4): 588-608.

Wainwright, T. (2009) Laying the foundations for a crisis: Mapping the historico-geographical construction of residential mortgage backed securitization in the UK. International Journal of Urban and Regional Research 33(2): 372-388.

Waldron R (2018) Capitalizing on the State: The Political Economy of Real Estate Investment Trusts and the 'Resolution' of the Crisis. Geoforum 90: 206-218

Watson M (2010) House price Keynesianism and the contradictions of the modern investor subject. Housing Studies 25(3): 413-426.

Wijburg, G. and Aalbers, M.B. (2017) The alternative financialization of the German housing market. Housing Studies 32(7): 968-89.

Wijburg, G., Aalbers M.B., and Heeg, S. (2018) The Financialization of Rental Housing 2.0: Releasing Housing into the Privatized Mainstream of Capital Accumulation. Antipode 50(4): 1098-1119.

Wind, B. (2017). Housing Wealth in Europe: Institutions and Inequality. PhD Dissertation. Tilburg: Universiteit van Tilburg. 
Figure 1. Tenure composition of the Dutch housing stock 1947-2017

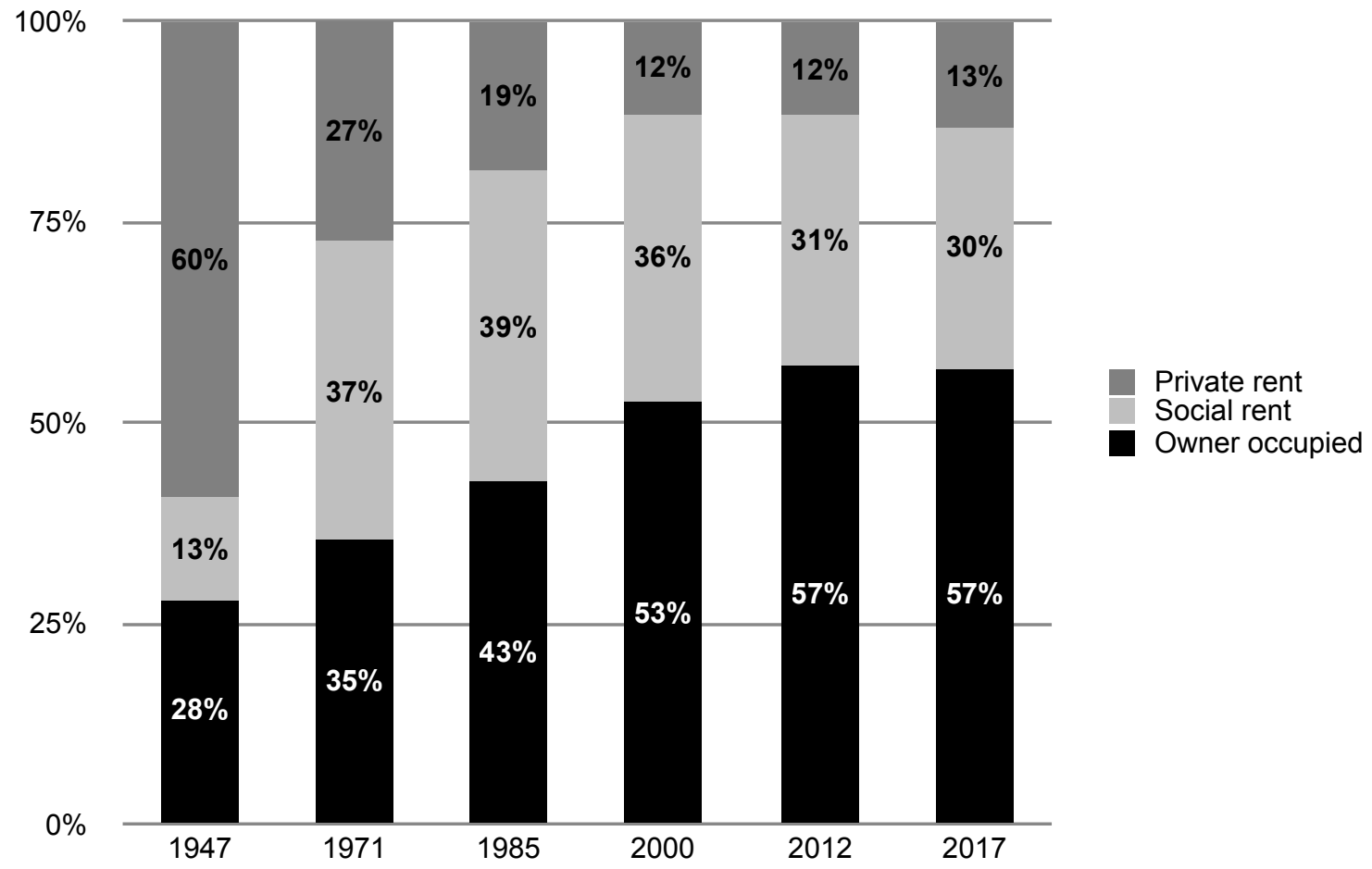

Source: 1947-2000 data reproduced from Musterd (2014), 2012-2017 data from CBS (2019). Note: Social rent is owned by housing associations; private rent by private landlords.

Figure 2. Sale of housing association units to households and investors (absolute numbers)

18000

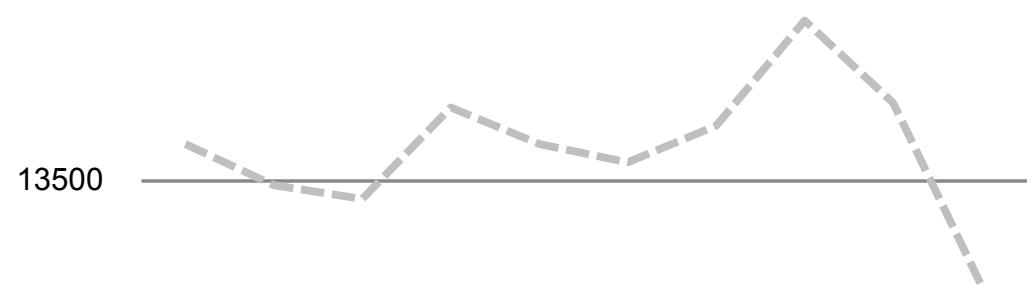

- Sales to investors and others -- Sales to private households

9000

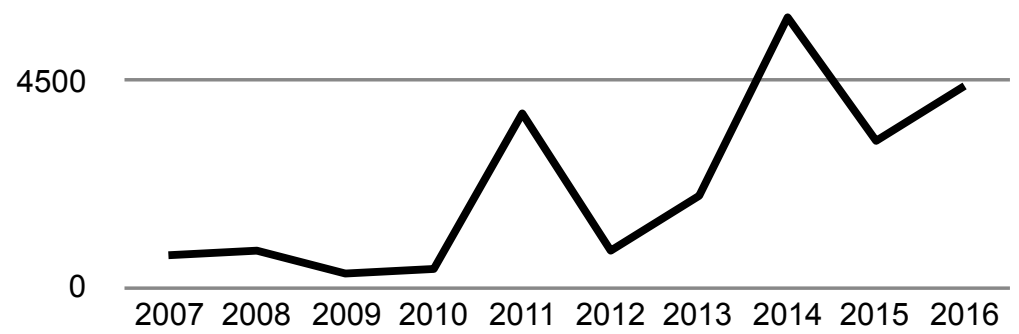

Source: Based on Aedes.nl data. 
Figure 3. Absolute number of new-build rental units bought by investors 2008-2018

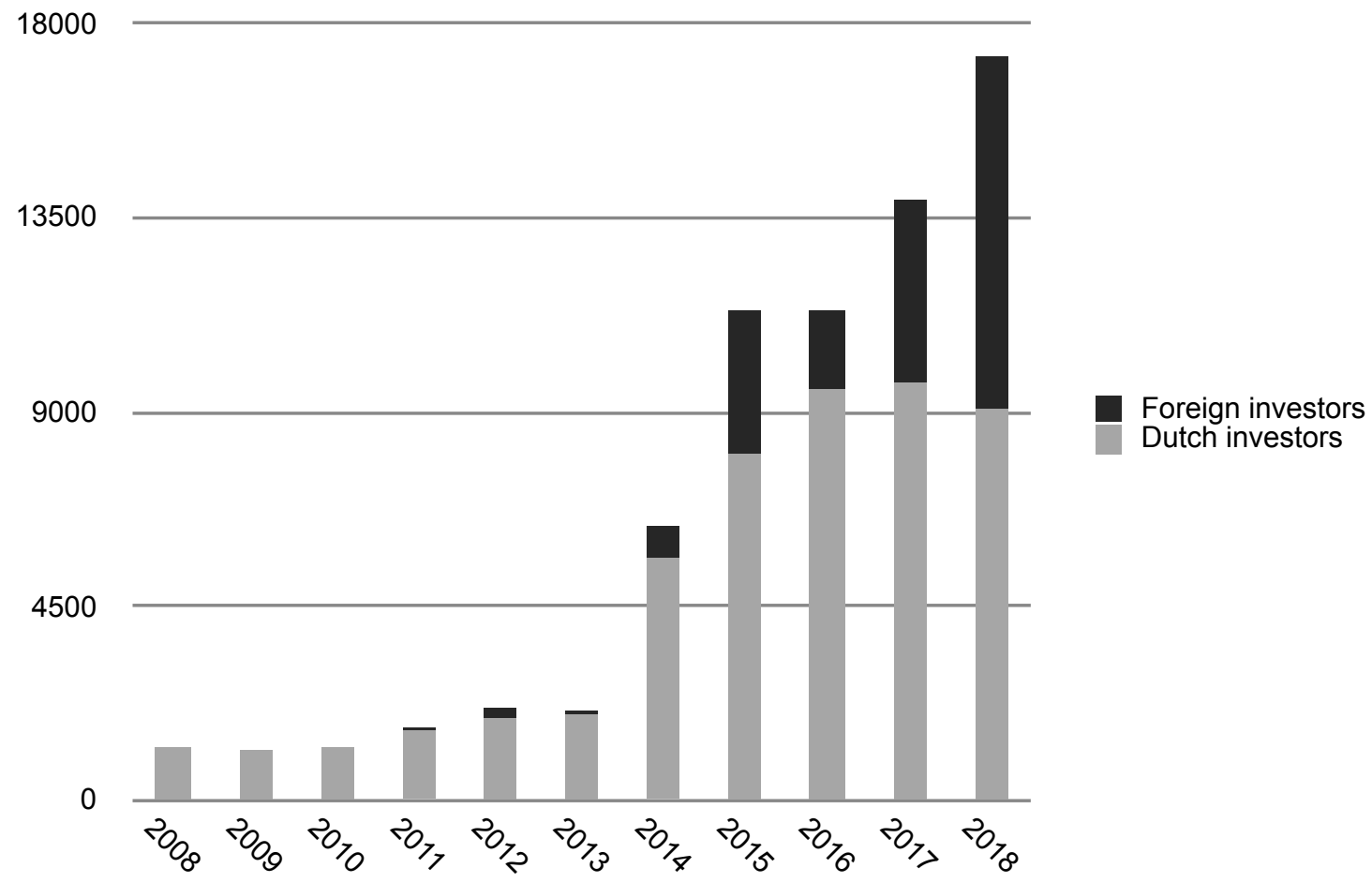

Source: Conijn (2019); Ministry of the Interior (2019).

Figure 4. Purchase for rental by private individuals with three to fifty dwellings as a share of the total number of transactions in the four major cities, and the Netherlands on average between 2006 and 2016

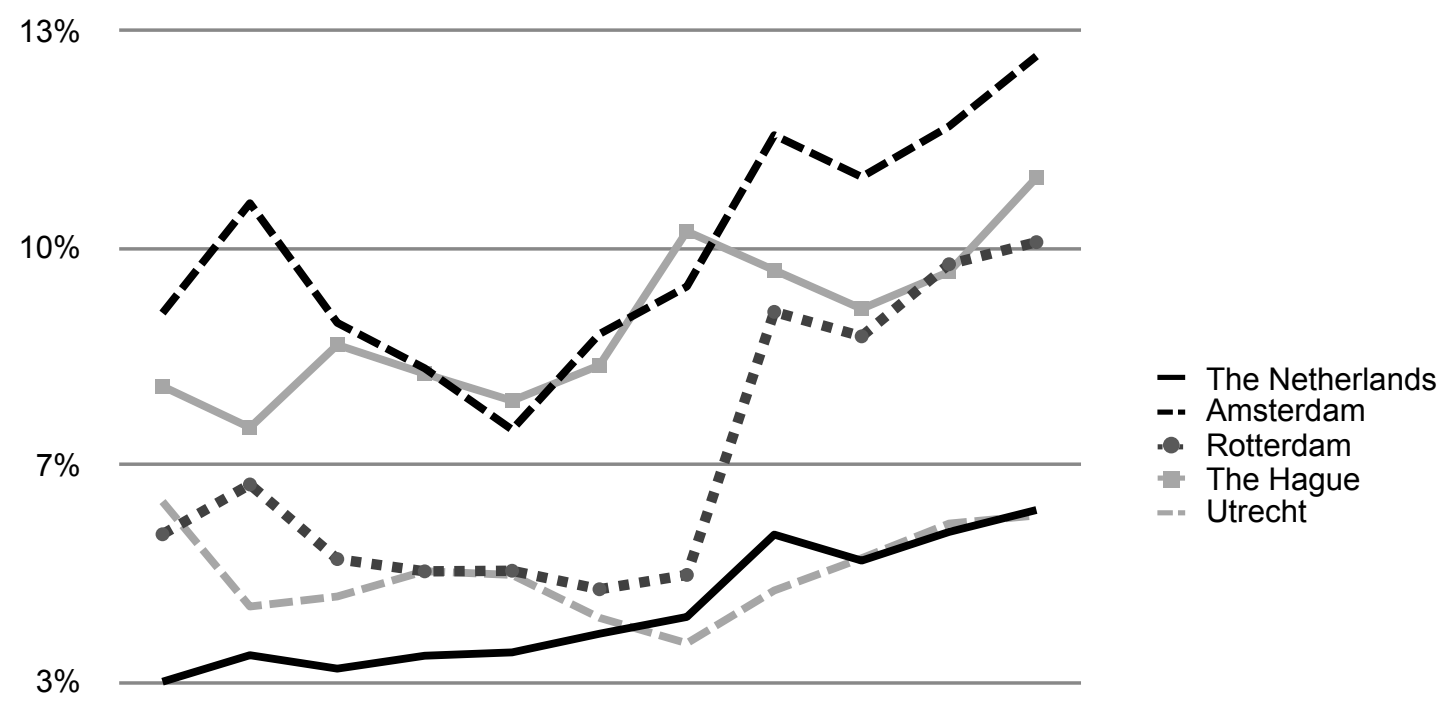

0\% 20062007200820092010201120122013201420152016

Source: Based on Land Registry data (Kadaster). Note: dates for 2016 up to and including $Q 3$. 
Figure 5. The 2016 share of house purchases by private individuals with two, or three to fifty dwellings as a share of the total number of transactions in selected cities and the Netherlands

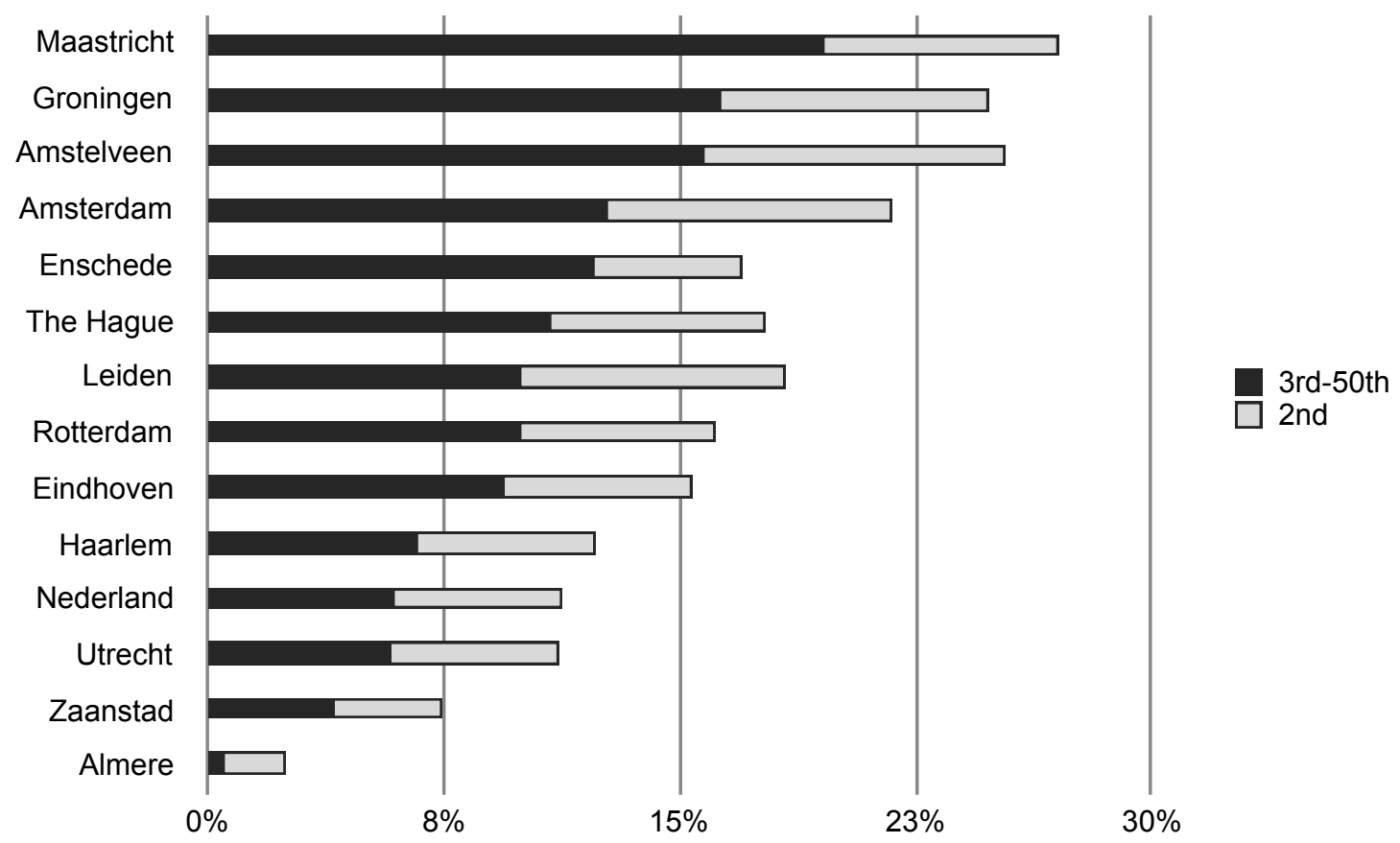

Source: $\quad$ Based on Land Registry data (Kadaster). Note: data go up to and include Q3 of 2016. 